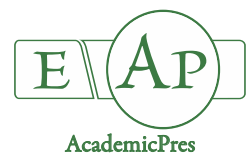

\title{
Somatic Embryogenesis Induction in Leaf and Root Explants of Allophylus edulis (A.St.-Hil., Cambess. and A. Juss.) Radlk.
}

\author{
Thiago da Silva MESSIAS ${ }^{1}$, Rodrigo Kelson Silva REZENDE ${ }^{2}$, \\ Luciely Faustina da SILVA ${ }^{1}$, Maílson Vieira JESUS ${ }^{2 *}$, Geisianny Pereira NUNES ${ }^{1}$ \\ ${ }^{1}$ Federal University of Grande Dourados, Faculty of Biological and Environmental Sciences, Highway Dourados - Itahum, Km 12 - University \\ City, mailbox 364 -Zip Code 79804-970,Dourados, MS, Brazil; thiagom896@gmail.com; lucielyfs@gmail.com; geisi.pn@hotmail.com \\ ${ }^{2}$ Federal University of Grande Dourados, Faculty of Agrarian Sciences, Highway Dourados - Itabum, Km 12 - University City, mailbox 364 - \\ Zip Code 79804-970,Dourados, MS, Brazil; rkelson@ufgd.edu.br; mvjagro@gmail.com (*corresponding author)
}

\begin{abstract}
Allophylus edulis (A.St.-Hil., Cambess. and A. Juss.) Radlk., commonly known as cocum, belongs to the Sapindaceae family. This species is of great medicinal interest, with studies showing that its fruits have antioxidant, anti-cholinesterase, and cytotoxic activity. In addition, it is used in traditional medicine as an antidiarrheal, anti-inflammatory and antihypertensive. The objective of this study was to perform somatic embryogenesis in vitro from leaf and root explants of Allophylus edulis, using different 6-benzylaminopurine (BAP) concentrations combined with naphthalene acetic acid (NAA). All treatments exhibited $100 \%$ callus formation, except for the treatment without supplementation of growth regulators. The calluses developed in treatments from leaf explants showed up to two colors (brown and brown/cream), and the highest fresh and dry mass was observed in the treatment with $0.5 \mathrm{mg} \mathrm{L}^{-1}$ of BAP with $0.1 \mathrm{mg} \mathrm{L}^{-1}$ of NAA. There was no shoot formation from the leaf explants. The callogenesis in treatments from root segments showed callus formation with up to three colors (brown, brown/cream, and cream/green), and the highest fresh and dry mass was obtained when cultivated with $2.0 \mathrm{mg} \mathrm{L}^{-1}$ of BAP combined with $0.1 \mathrm{mg} \mathrm{L}^{-1}$ of NAA. These auxin and cytokinin concentrations also showed a higher number of shoots. The interaction between auxin and cytokinin is recommended to obtain somatic embryogenesis in root segments and callus with morphological characteristics suitable for organogenesis.
\end{abstract}

Keywords: in vitro morphogenesis; plant biotechnology; plant regulators

\section{Introduction}

The species Allophylus edulis (A.St.-Hil., Cambess. and A.Juss.) Radlk., is part of the native Brazilian flora from the family Sapindaceae, and is subordinate to the order Sapindales, which encompasses 12 families, 460 genera and 5670 species (Buerki et al., 2010). Allophylus edulis is commonly known by several different common names in Portuguese, "chal-chal", "fruto-do-pombo", "vacunzeiro" and "murta vermelha" (Lorenzi, 2002). In some southern regions, it is known as "vacuum" (Somner et al., 2013), while in the Midwest and on the border with Paraguay it is called "cocum" (Alves et al., 2008). Allophylus edulis has red, sweet, edible fruits (Franco and Fontana, 2011), and occurs naturally in parts of South America and in the Brazilian territory, where its distribution ranges from the Northern to the Southern region (Pasqualli et al., 2015).
This species is of great medicinal importance, as its leaves are used in popular medicine as an antidiarrheal (Alves et al., 2008), anti-inflammatory and antihypertensive (Korbes, 1995), for their genotoxic activity (Yajia et al., 1999), and as an insect repellant (Castillo et al., 2009). Its fruits also have antioxidant, anti-cholinesterase and cytotoxic activities (Umeo et al., 2011). Studies have shown that the antimicrobial and antioxidant activity of ethanolic extracts of $A$. edulis leaves were not toxic in rats (Tirloni et al., 2015).

In vitro cultivation allows the development of new techniques, such as the genetic transformation of plants, and is of great importance for species that present difficulties in propagating by other vegetative or seeding methods (Ferreira et al., 2015). In vitro cultivation techniques are essential to produce doubled haploids, obtain virus-free plants and produce secondary metabolites or recombinant proteins in plant cells in suspension (Dagla, 2012). The 
1082

presence of growth regulators or plant hormones in the culture medium are essential for plant regeneration in vitro and are responsible for inducing physiological responses such as sprouting, rooting and cell elongation (Cid, 2010). Growth regulators are synthetic substances with hormonelike effects (Hinojosa, 2005), with the main classes being cytokinins and auxins (Hussain et al., 2012). Cytokinins promote cell division and are related to adenine (Cid, 2010), while auxins are important for the induction of somatic embryogenesis (Fehér, 2005).

Somatic embryos have great advantages, such as unlimited production of clones with elite characteristics, basic functional and molecular research, synthetic seed production and conservation of genetic resources by cryopreservation (Aslam et al., 2011). Somatic embryos originate from a single cell or somatic cell groups that grow and differentiate into embryos when grown in a suitable culture (Rocha et al., 2016). They can originate via direct or indirect routes. The direct route occurs when the embryo originates from the matrix tissues without forming calluses, while the indirect route occurs when the embryo develops from a callus (Rizvi et al., 2013). Several factors influence the ability to obtain somatic embryos, such as the source of explants, genotype of the donor plant, and the type and concentrations of growth regulators (Ahmadi et al., 2014).

The objective of this study was to perform in vitro somatic embryogenesis from leaf and root explants of Allophylus edulis using different concentrations of 6benzylaminopurine (BAP) combined with naphthalene acetic acid (NAA).

\section{Materials and Methods}

\section{Study site description and plant material}

The experiment was conducted at the Plant Biotechnology Laboratory of the Center for Biotechnology and Genetic Improvement of Sugarcane at the Federal University of Grande Dourados (UFGD). In vitrogerminated Allophylus edulis individuals at 60 days of age were the source of explants used in the experiment. The seedlings were removed from test tubes one by one in a horizontal laminar flow chamber. Then, the leaves and roots were excised to obtain leaf explants of approximately 1.0 $\mathrm{cm}^{2}$, maintaining the central vein and root segments of approximately $1.0 \mathrm{~cm}$.

\section{Explants inoculation and the treatments of growth regulators}

Leaf explants were inoculated with the abaxial portion in contact with the culture medium, while the root segments were inoculated horizontally. Both explants were inoculated into test tubes with $15 \mathrm{~mL}$ of MS culture medium (Murashige and Skoog, 1962), solidified with $6.0 \mathrm{~g}$ $\mathrm{L}^{-1}$ agar, with an additional $30 \mathrm{~g} \mathrm{~L}^{-1}$ sucrose and supplemented with different concentrations of BAP (control, 0.0; T1, 0.25; T2, 0.5; T3, 1.0; and T4, $2.0 \mathrm{mg} \mathrm{L}^{-1}$ ) combined with NAA $\left(0.1 \mathrm{mg} \mathrm{L}^{-1}\right)$. The $\mathrm{pH}$ was adjusted to $5.8 \pm 0.1$ before autoclaving at $121^{\circ} \mathrm{C}$ and pressure of 1.05 $\mathrm{kg} \mathrm{cm}^{-2}$ for 20 minutes.

After inoculation, the plant material was kept in a growth room at $25 \pm 2{ }^{\circ} \mathrm{C}$ for 7 days in the absence of light and was subsequently kept under a 16-hour photoperiod $\left(45 \mu \mathrm{mol} \mathrm{m} \mathrm{m}^{-2} \mathrm{~s}^{-1}\right.$ supplied by white fluorescent lamps. Fortyfive days after the experiment commenced, the percentage of explants with callus, fresh and dry mass of the callus, consistency (friable or compact), color, number of shoots and percentage of explants with shoots were evaluated. The experiment followed a completely randomized design and consisted of five treatments with five replicates each. Each replicate was composed of five test tubes.

\section{Statistical procedures}

The data were analyzed using an analysis of variance and, when significant, the means were compared using a Tukey's test, at a $1 \%(\mathrm{p}<0.01)$ level of error probability. The numerical data (fresh mass, dry mass, and number of shoots) were transformed into square root of $x+0.5$, while the percentage of callus explants were not transformed. Data analysis was performed using the software GENES (Cruz, 2013).

\section{Results}

After 45 days of inoculation, a significant difference was observed for all evaluated variables in the different types of explants used in the experiment (leaf and root), except for consistency where all treatments presented as 100\% compact. Callus induction also provided $100 \%$ callus formation, except for the control treatment (T0), where calluses were not formed (data not shown). The BAP and NAA combinations used in the treatments resulted in callogenesis with up to two colors in the same callus in leaf explants, and up to three colors for root explants. In T3 treatments with leaf explants, calluses were only brown colored (100\%); in T1 and T2, $82.4 \%$ of calluses were brown and $17.6 \%$ were brown/cream colored, and; T4 were brown and brown/cream colored (71.4 and 28.6\%, respectively) (Fig. 1).

$\mathrm{T} 1$ and $\mathrm{T} 2$ in the root segments treatments presented with more colors, i.e., both had calluses with up to three colors: brown, brown/cream and brown/green, with $\mathrm{T} 1$ being $64 \%, 32 \%$ and $4 \%$, respectively and T2 with $28 \%$, $48 \%$ and $20 \%$, respectively. T3 and T4 had calluses with up to two colors, with T3 having brown and brown/cream calluses (20\% and $80 \%$, respectively). However, the T4 treatment was the only one to present calluses with a cream/green color (76\%), while $24 \%$ of the calluses had brown coloring (Fig. 2).

The BAP and NAA combinations in the treatments cultivated with leaf and root explants provided significant differences at the $1 \%$ level, showing an interaction between the concentrations used and the variables fresh and dry mass (Table 1). The leaf explants treatments differed statistically among each other, with T2 exhibiting the highest mean (1.262) when compared to those of the other treatments. The mean of T2 was not statistically different from that of T4, which had the second highest value (1.092). However, the mean of T2 did differ significantly from that of T1 (0.962) and T3 (0.986), which presented the smallest averages among treatments. The means of T1 and T3 did not differ between each other or that of $\mathrm{T} 4$. The overall mean of the fresh mass for leaf explants is 1.075 (coefficient of variation; $\mathrm{CV}=10.5 \%$ ). 
Significant differences were observed for the dry mass in the treatments from leaf explants. T2 had the highest mean $(0.765)$ that was not statistically different from that of T4, with the second highest value (0.710), but did differ significantly from that of T1 (lowest mean; 0.661) and T3 (second lowest mean; 0.674 ) at a $1 \%$ probability level. The means of treatments T1 and T3 did not differ from each other and were statistically equivalent to that of T4. The overall mean for the dry mass of the treatments cultivated from leaf explants was $0.702(\mathrm{CV}=5.4 \%)$.

The interaction between plant regulator concentrations used in treatments with root segments showed a significant difference among treatments $(\mathrm{p}<0.01)$. The highest means obtained for the fresh mass in the treatments from root segments were recorded in treatments T4 and T2 (on average 0.989 and 0.893 , respectively) and the lowest means were found in T3 and T1 (0.854 and 0.810, respectively). The mean of group T4 (0.989) did not differ statistically from that of T2 (0.893). However, the mean of T4 did differ statistically from that of $\mathrm{T} 1$, which presented the lowest mean (0.810), and of T3 (0.854), though these did not differ from each other and were statistically equivalent to the mean of T2. The overall mean for the fresh mass for root segments was $0.887(\mathrm{CV}=5.8 \%)$.

The dry mass of calluses cultivated from root segments exhibited significant differences between treatments. T4 had the highest mean dry mass value $(0.677)$ when compared with the other treatments and differed statistically from that of T1 with the lowest value (0.673).
However, the mean of T4 was not statistically different from the mean of $\mathrm{T} 2$ or $\mathrm{T} 3$ (with respective means of 0.638 and 0.637 ). The means of T2 and T3 were intermediate to those of T1 and T4. The mean of T1 was statistically equivalent to that of T2 and T3. The concentrations used in treatments with root segments showed significant differences, with the overall average for the dry mass treatments being $0.641(\mathrm{CV}=3.2 \%)$.

The treatments from leaf explants did not show shoot formation (data not shown), indicating that the interaction of BAP with NAA did not contribute to its development. However, shoot formation of treatments from root segments differed $(\mathrm{p}<0.01)$ (Table 01). The highest mean values for the number of shoots in the treatments cultivated with root segments were observed in treatments T4 and T2 (1.545 and 1.250, respectively). These means did not differ statistically from each other but did from that of the treatments with the lowest means, namely T3 and T1 (0.590 and 0.626$)$, which were statistically equivalent. The mean number of shoots was $1.003(\mathrm{CV}=22.5 \%)$.

Only treatments developed from root segments showed shoot formation, as seen in the percentage of explants with shoot development. The interaction of BAP with NAA produced a difference amongst all treatments in the percentage of explants with shoots, such that T4 exhibited a higher percentage of root segments with $44 \%$, compared with that from T1 (8\%), T2 (25\%) and T3 (20\%) at a 1\% probability level. The treatment with the lowest shoot rate was T1 with only $8 \%$.

Table 1. Different treatments effect on on fresh mass, dry matter and number of shoots of leaf and root explants of Allophylus edulis

\begin{tabular}{|c|c|c|c|c|c|}
\hline \multirow{2}{*}{ Treatments } & \multicolumn{2}{|c|}{ Leaf } & \multicolumn{3}{|c|}{ Root } \\
\hline & Fresh masss (g) & Dry mass (g) & Fresh masss (g) & Dry mass (g) & Number of shoots \\
\hline $\mathrm{T} 1$ & $0,962 \mathrm{~b}$ & $0,661 \mathrm{~b}$ & $0,810 \mathrm{~b}$ & $0,613 b$ & $0,626 b$ \\
\hline $\mathrm{T} 2$ & $1,262 a^{* *}$ & $0,765 a^{* *}$ & $0,893 \mathrm{ab}$ & $0,638 \mathrm{ab}$ & $1,250 \mathrm{a}$ \\
\hline T3 & $0,986 \mathrm{~b}$ & $0,674 b$ & $0,854 \mathrm{~b}$ & $0,637 \mathrm{ab}$ & $0,590 \mathrm{~b}$ \\
\hline $\mathrm{T} 4$ & $1,092 \mathrm{ab}$ & $0,710 \mathrm{ab}$ & $0,989 a^{* *}$ & $0,677 a^{* *}$ & $1,545 a^{* *}$ \\
\hline MG & 1,075 & 0,702 & 0,887 & 0,641 & 1,003 \\
\hline $\mathrm{CV}(\%)$ & 10,5 & 5,4 & 5,8 & 3,2 & 22,5 \\
\hline
\end{tabular}

Note: ${ }^{* *}$ significant at the $1 \%$ probability level $(\mathrm{p}<0.01)$ by the F test. BAP levels (T1: $\left.0.25 \mathrm{mg} \mathrm{L}^{-1}, \mathrm{~T} 2: 0.5 \mathrm{mg} \mathrm{L}^{-1}, \mathrm{~T}^{2}: 1.0 \mathrm{mg} \mathrm{L}^{-1}, \mathrm{~T} 4: 2.0 \mathrm{mg} \mathrm{L}^{-1}\right)$ combined with $0.1 \mathrm{mg}$ $\mathrm{L}^{-1}$ of ANA, 45 days after inoculation

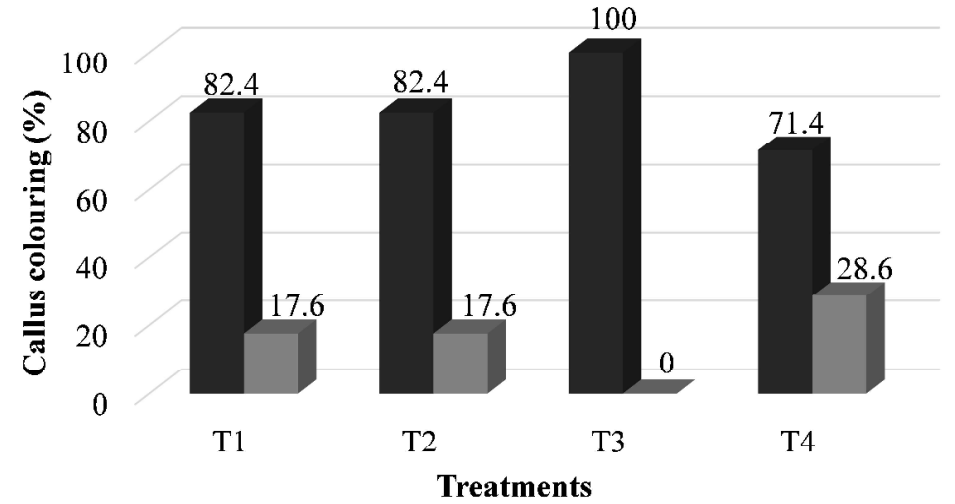

brown brown/cream

Fig. 1. Callus colouring on leaf explants of Allophylus edulis according to BAP levels (T1: $0.25 \mathrm{mg} \mathrm{L}^{-1}$; T2: $0.5 \mathrm{mg} \mathrm{L}^{-1}$; T3: $1.0 \mathrm{mg}$ $\mathrm{L}^{-1}$; T4: $2.0 \mathrm{mg} \mathrm{L}^{-1}$ ) combined with $0.1 \mathrm{mg} \mathrm{L}^{-1}$ of NAA, 45 days after inoculation (in percentage) 
1084

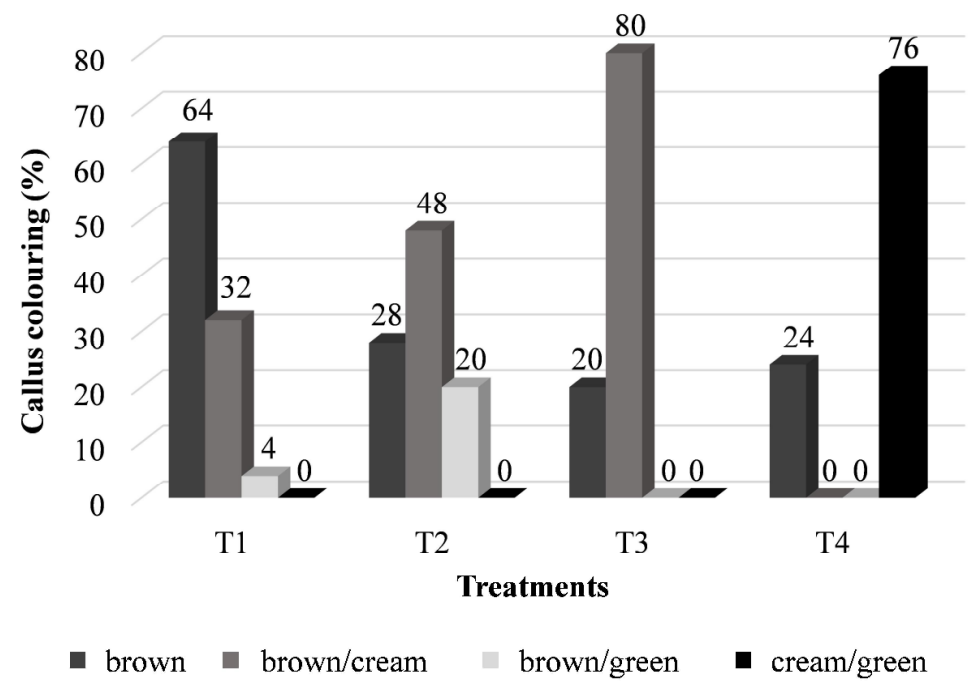

Fig. 2. Callus colouring on root explants of Allophylus edulis according to BAP levels (T1: $0.25 \mathrm{mg} \mathrm{L}^{-1}$; T2: $0.5 \mathrm{mg} \mathrm{L}^{-1}$; T3: $1.0 \mathrm{mg}$ $\mathrm{L}^{-1}$; T4: $2.0 \mathrm{mg} \mathrm{L}^{-1}$ ) combined with $0.1 \mathrm{mg} \mathrm{L}^{-1}$ of NAA, 45 days after inoculation (in percentage)

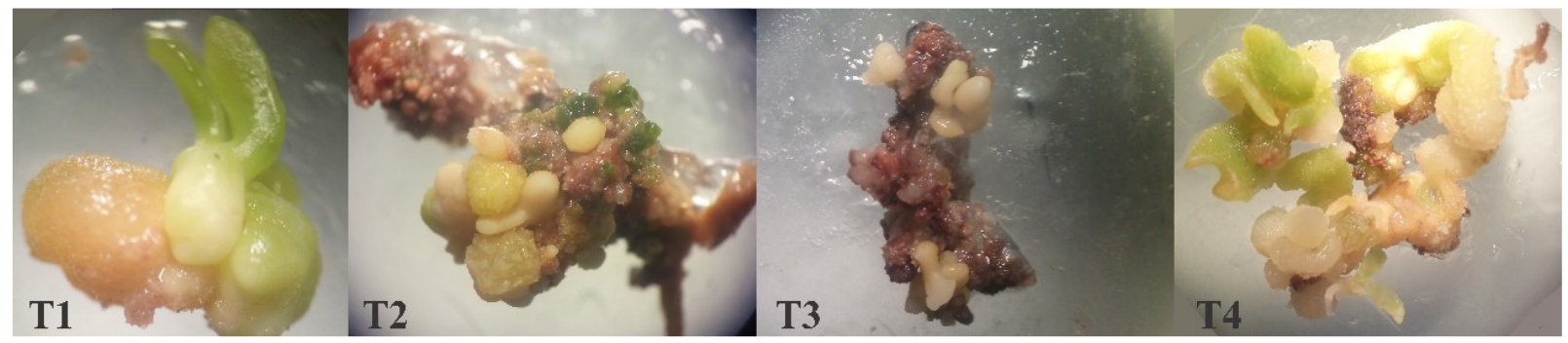

Fig. 3. Shoots aspects in Allophylus edulis root segments grown under different concentrations of BAP (T1 - 0.25, T2 - 0.5, T3 1.0 and $\mathrm{T} 4-2.0 \mathrm{mg} \mathrm{L}^{-1}$ ) combined with $0.1 \mathrm{mg} \mathrm{L}^{-1}$ of NAA, 45 days after inoculation

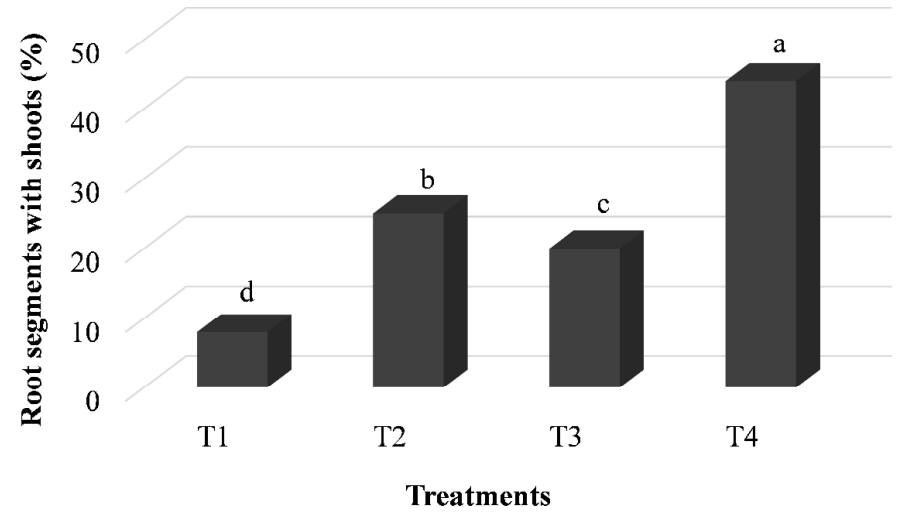

Fig. 4. Percentage of root segments with bud formation at different BAP levels (T1: $0.25 \mathrm{mg} \mathrm{L}^{-1}$; $\mathrm{mg} \mathrm{L}^{-1}$, T3: 1.0 mg L-1, T4: 2.0 $\mathrm{mg} \mathrm{L}^{-1}$ ) combined with $0.1 \mathrm{mg} \mathrm{L}^{-1}$ of NAA, 45 days after inoculation. Means followed by distinct letters differ from each other by the $\mathrm{F}$ test at the $1 \%$ probability level $(\mathrm{p}<0.01)$

\section{Discussion}

There was no difference in the consistency of the calluses developed in the treatments with different concentrations of BAP combined with NAA. The calluses developed were all compact, in agreement with George et al. (2013), who observed that low concentrations of auxin and high concentrations of cytokinin produce compact calluses. The ability to form compact calluses is among the parameters used to indicate the regenerative capacity of the plant material (Rodrigues et al., 2009). In this study, it was possible to observe compact calluses in all treatments with different concentrations of auxin when using low auxin concentration in comparison to cytokinin, similar to the 
results obtained by George et al. (2013). The calluses grown from root segments presented with up to three colors, namely brown, brown/cream, brown/green or cream/green. On the other hand, treatments with leaf explants presented two colors (brown and brown/cream). Carvalho et al. (2015) observed that calluses of Passiflora gibertii with clear and compact colors in leaves were more favorable for organogenesis.

The colors developed in treatments with root segments may be related to shoot formation. The treatment with root segment, where there were more light colored calluses (2.0 $\mathrm{mg} \mathrm{L}^{-1}$ of BAP with $0.1 \mathrm{mg} \mathrm{L}^{-1}$ of NAA; $76 \%$, cream/green), differed from the other treatments regarding shoot formation. Under suitable culture conditions where there is balance between growth regulators, groups of cells that have active centers may be induced to differentiate into organs. These cells are called competent because of their ability to react to certain stimuli, resulting in shoot or root formation (George et al., 2013).

The calluses of different treatments, when cultivated with root segments, presented shoot formation. However, when cultivated with leaf explants, they did not develop shoots, indicating that there was an intermediate hormonal balance of the growth regulators. The concentrations of auxin and endogenous cytokinin in the leaves of $A$. edulis probably induced a balance in the growth regulators, which did not occur in root segments, showing that the endogenous concentrations of auxin and cytokinin are different in leaf and root explants of $A$. edulis. These results corroborate with the study of Anwar et al. (2015), where they found the endogenous growth hormone content and the type of growth hormone is directly related to each explant source.

For Nogueira et al. (2007), callus formation depended on an intermediate hormonal balance of auxin and cytokinin. In many cases, the addition of a plant regulator to the crop is essential for callus formation (Pêgo et al., 2013). This exogenous supplementation of growth regulators can provide the plant cells with a higher totipotency to regenerate (Garcia et al., 2011). The concentrations and type of endogenous and exogenous growth regulators are factors that generate several events at the molecular level, affecting the transcription of genes responsible for cell differentiation (Rosa et al., 2015).

Dibax et al. (2010) compared three combinations of NAA and Thidiazuron (TDZ, resulting in a callus formation of $73 \%$ when using $0.1 \mu \mathrm{M}$ NAA with $1.0 \mu \mathrm{M}$ TDZ, showing that the interaction between auxin and cytokinin stimulates callogenesis. BAP and NAA interactions showed differences among treatments for fresh and dry mass of leaf and root explants. Fresh and dry mass and higher concentrations of BAP were not directly related in treatments with leaf explants, indicating that a hormonal balance between growth regulators is required for greater cell proliferation in $A$. edulis leaf explants. This hormonal balance for callus formation with greater fresh and dry mass can be achieved with different concentrations of BAP combined with $0.1 \mathrm{mg} \mathrm{L}^{-1}$ of NAA.

In the absence of a plant regulator, Schizolobium amazonicum (paricá) showed a reduced frequency of callus formation (Cordeiro et al.2004). Cordeiro et al. (2004) also found that callus mass is directly related to the increase of the BAP regulator, as was observed in this study in the treatments cultivated with root segments. As the BAP concentration increased, a callus formation with higher mass was recorded compared to the callus developed in lower concentrations of BAP.

\section{Conclusions}

Callus formation in leaf explants of Allophylus edulis requires growth regulator supplementation. The combination of $0.5 \mathrm{mg} \mathrm{L}^{-1}$ of BAP with $0.1 \mathrm{mg} \mathrm{L}^{-1}$ of NAA provides calluses with higher fresh and dry mass and up to two colors. It was clear in this experiment that root segments are more suitable for obtaining somatic embryos. The use $2.0 \mathrm{mg} \mathrm{L}^{-1}$ of BAP combined with $0.1 \mathrm{mg} \mathrm{L}^{-1}$ of NAA is advised to form the largest number of shoots.

\section{Conflict of Interest}

The authors declare that there are no conflicts of interest related to this article.

\section{References}

Ahmadi B, Shariatpanahi ME, Silva JAT (2014). Efficient induction of microspore embryogenesis using absćíico acid, jasmonic acid and salicylic acid in Brassica napus L. Plant Cell, Tissue and Organ Culture 116(3):343-351.

Alves EOM, Soares TS, Vieira MC, Silva CB (2008). Etnobotanical survey and medicinal plants characterization in forest fragments in DouradosMS. Ciência e Agrotecnologia 32(2):651-658.

Anwar N, Kikuchi A, Watanabe KN (2015). Assessment of somaclonal variation for salinity tolerance in sweet potato regenerated plants. African Journal of Biotechnology9(43):7256-7265.

Aslam J, Khan SA, Cheruth, AJ, Mujib A, Sharma MP, Srivastava PS (2011).Somatic embryogenesis, scanning electron microscopy, histology and biochemical analysis at different developing stages of embryogenesis 16 in six date palm (Phoenix dactylifera L.) cultivars. Saudi Journal of Biological Sciences 18(4):369-380.

Buerki S, Lowry II PP, Alvarez N, Razafimandimbison SG, Küpfer P, Callmander MW (2010). Phylogeny and circumscription of Sapindaceae revisited: molecular sequence data, morphology and biogeography support recognition of a new family, Xanthoceraceae. PlantEcology and Evolution 143(2):148-159.

Carvalho MAF, Paiva R, Herrera RC, Alves E, Castro EM, Paiva PDO, Vargas DP (2015). Induction, morphologic and ultra-structural analyses of native passion fruit calluses. Revista Ceres 62(4):340-346.

Castillo L, Gonzalez-Coloma A, Gonzalez A, Diaz M, Santos E, Alonso-Paz, ... Rossini C (2009). Screening of Uruguayan plants for deterrent activity against insects. Industrial Crops and Products 29(1):235-240.

Cid LPB (2010). Cultivo in vitro de plantas [Plants in vitro cultivation]. Embrapa Informação Tecnológica (3rded), Braslia.

Cordeiro IMCC, Lameira AO, Ohashi ST, Rosal LF (2004). Effect of bap on proliferation of Schizolobium amazonicum Huber ex Ducke (Parica) shoots, in vitro. Cerne 10(1):118-124. 
1086

Cruz CD (2013). GENES - a software package for analysis in experimental statistics and quantitative genetics. Acta Scientiarum 35(3):271-276.

Dagla, HR(2012). Plant tissue culture. Resonance 17(8):759-767.

Dibax R, Deschamps C, Bespalhok Filho JC, Vieira LGE, Molinari HBC, De Campos MKF, Quoirin, M (2010). Organogenesis and Agrobacterium tumefaciens mediated transformation of Eucalyptus saligna with P5CS gene. Biologia Plantarum 54(1):6-12.

Fehér A (2005). Why somatic plant cells start to form embryos? In: Mujib A, Šamaj J (Eds). Somatic Embryogenesis. Springer, Berlin, Heidelberg, pp 85-101.

Ferreira DAT, Sattler MC, Carvalho CR, Clarindo WR (2015). Embryogenic potential of immature zygotic embryos of Passiflora: a new advance for in vitro propagation without plant growth regulators. Plant Cell, Tissue and Organ Culture 122:629-638.

Franco IJ, Fontana VL (2011). Ervas e plantas: a medicina dos simples [Herbs and plants: a medicine of the simple].Edelbra (12thed),Erexim.

Garcia R, Pacheco G, FalcãoE, Borges G, MansurE (2011). Influence of type of explant, plant growth regulators, salt composition of basal medium, and light on callogenesis and regeneration in Passiflora suberosa $\mathrm{L}$. (Passifloraceae). Plant Cell, Tissue and Organ Culture 106(1):47-54.

George EF, Hall MA, Klerk GJ (2013). Plant propagation by tissue culture. Springer(3rded), Dordrecht.

Hinojosa GF (2005). Auxina em plantas superiores: síntese e propriedades fisiológicas [Auxin in higher plants: synthesis and physiological properties]. In: Cid LPB (Ed). Hormônios vegetais em plantas superiors [Plant hormones in higher plants]. Embrapa Recursos Genéticos e Biotecnologia, Brasilia, pp 15-57.

Hussain A, Qarshi IA, Nazir H, Ullah I (2012). Plant tissue culture: current status and opportunities. In: Leva A, Rinaldi LMR (Eds). Recent advances in plant in vitro culture. In Tech, Croatia, pp 210.

Korbes VC (1995). Plantas medicinais [Medicinal plants]. Grafit 48:101120.

Lorenzi H (2002). Árvores brasileiras: manual de identificação e cultivo de plantas arbóreas nativas do Brasil [Brazilian trees: identification and cultivation of native tree plants in Brazil]. Plantarum (3th ed), São Paulo.

Murashige T, Skoog F (1962). A revised medium for rapid growth and bioassays with tobacco tissue cultures. Physiologia Plantarum 15(3):473-497.

Nogueira RC, Paiva R, Oliveira LM, Soares GA, Soares FP, Castro AHF, Paiva PDO (2007). Calli induction from leaf explants of muricipequeno (Byrsonima intermedia A. Juss.). Ciência e Agrotecnologia 31(2):366-370.
Pasqualli M, Tedesco M, Tedesco SB (2015). Antiproliferative and genotoxic potential of Allophylus edulis (A.St.-Hil., Cambess. \& A. Juss.) Radlk. by the Allium cepa L. test. Enciclopédia Biosfera, Centro Científico Conhecer 11(21):2365-2372.

Pêgo RG, Paiva PDO, Paiva R (2013). Micropropagation of Syngonanthus elegantulus. Ciência e Agrotecnologia 37(1):32-39.

Rizvi MZ, Das S, Sharma MP, Srivastava PS (2013). Somatic embryogenesis in monocots. In: Aslam J, Srivastava PS, Sharma MP (Eds). Somatic embryogenesis and gene expression. Narosa Publishing House, New Delhipp 18-34.

Rocha DI, Pinto DLP, Vieira LM, Tanaka FAO, Dornelas MC, Otoni WC (2016). Cellular and molecular changes associated with competence acquisition during passion fruit somatic embryogenesis: ultrastructural characterization and analysis of SERK gene expression. Protoplasma253(2):595-609.

Rodrigues M, Paiva R, Nogueira RC, Martinotto C, Silva Junior JM (2009). In vitro morphogenesis of neem from cotyledonary-derived explants. Revista Árvore 33(1):21-26.

Rosa YBCJ, Monte Bello CC, Dornelas MC (2015). Species dependent divergent responses to in vitro somatic embryo induction in Passiflora spp. Plant Cell Tissue and Organ Culture 120(1):69-77.

Somner GV, Ferrucci MS, Acevedo-Rodríguez P (2013). Allophylus. In: Lista de Espécies da Flora do Brasil [List of Species of Flora of Brazil]. Jardim Botânico do Rio de Janeiro, Rio de Janeiro.

Tirloni CAS, Macorini LFB, Santos UP, Rocha PS, Barros SV, Melo AMM, ... Santos EL (2015). Evaluation of the antioxidant activity, antimicrobial effect and acute toxicity from leaves of Allophylus edulis (A. St.-Hil,, A. Juss. Cambess \&.) Hieron. ex Niederl. African Journal of Pharmacyand Pharmacology $9(11): 353-362$

Umeo SH, Ito TM, Yokota ME, Romagnolo MB, Laverde-Junior A (2011). Evaluation of antioxidant, cytotoxic and anticholinesterase properties of Allophylus edulis (A.ST.-Hil., Cambess. \& A. Juss.) Radlk. (Sapindaceae) fruits. Arquivo de Ciênciae Saúde 15(2):167-171.

Yajia ME, Martí DA, Bidau AG, Amat AG, Silvestroni A (1999). Genotoxicity evaluation of Allophylus edulis (Camb.) Radlk. (Sapindaceae) aqueous extract. Acta Horticulturae 501:31-35. 